\title{
PENGARUH HASIL PLACEMENT TEST DAN KECERDASAN UMUM(IQ) TERHADAP HASIL BELAJAR MATEMATIKA PEMINATAN SISWA KELAS $X$ IPA SMA NEGERI 1 TAJURHALANG
}

\author{
MOHAMAD TAOFIK \\ SMA Negeri 1 Tajurhalang, Jawa Barat \\ E-mail : opikcamuhe@yahoo.com
}

\begin{abstract}
ABSTRAK
Kegiatan PPDB SMAN 1 Tajurhalang dilanjutkan dengan proses penjurusan untuk menentukan program yang akan diikuti oleh peserta didik baru apakah program IPA, IPS. Penjurusan ini berpedoman pada hasil placement test dan hasil test kecerdasan umum atau test IQ. Berdasarkan ini lah maka penulis sebagai guru matematika peminatan mengadakan penelitian tentang Pengaruh Hasil Placement Test dan Kecerdasan Umum (IQ) terhadap Hasil Belajar Matematika Peminatan Siswa Kelas X IPA di SMAN 1 Tajurhalang. Tujuan penelitian ini adalah untuk mengetahui bagaimana pengaruh hasil Placement dan hasil test IQ terhadap hasil belajar matematika peminatan kelas X IPA di SMA Negeri 1 Tajurhalang. Hasil uji asumsi klasik didapat bahwa data hasil placement test (X1), hasil test IQ (X2) dan Hasil Belajar Matematika Peminatan (Y) merupakan data yang berdistribusi normal, tidak terjadi multikolinieritas, heteroskedisitas, sehingga asumsi linieritas terpenuhi. Nilai $R=0,380$, dan $\mathrm{R}$ Square $=0,144$, hal ini menunjukan korelasi yang rendah atau lemah tapi pasti dan pengaruh sebesar $14,4 \%$. Hasil uji t nilai Sig. $=0,116>0,05$. $\mathrm{t}_{\text {hitung }}=1,581<2,266$, dan Sig $=0,000<0,05$, dan nilai $t_{\text {hitung }}=3,859>2,266$. Ini menunjukan bahwa secara parsial placement test tidak berpengaruh sedangkan test IQ berpengaruh. Hasil Uji F didapat nilai Sig. $=0,000<0,05$, nilai $\mathrm{F}_{\text {hitung }}=$ $11,650<3,062$ menunjukan bahwa koefesien regresi $\mathrm{Y}$ atas X1 dan X2 signifikan atau berarti.

Kata Kunci : Placement test, kecerdasan umum(IQ), Matematika Peminatan
\end{abstract}

\section{ABSTRACT}

The PPDB activity of SMAN 1 Tajurhalang was continued with the majors process to determine the program to be followed by new students, whether it was a science program, social science program. This major is guided by the results of the placement test and the results of the general intelligence test or IQ test. Based on this, the writer as a specialization mathematics teacher conducted a research on the Effect of Placement Test Results and General Intelligence (IQ) on Mathematics Learning Outcomes for Students of Class X Science at SMAN 1 Tajurhalang. The purpose of this study was to determine how the influence of Placement results and IQ test results on learning outcomes of mathematics with specialization in class X IPA at SMA Negeri 1 Tajurhalang. The results of the classical assumption test show that the data from the placement test (X1), IQ test results (X2) and Specialization Mathematics Learning Outcomes (Y) are data that are normally distributed, there is no multicollinearity, heteroscedasticity, so that the linearity assumption is met. The value of $\mathrm{R}=0.380$, and $\mathrm{R}$ Square $=0.144$, this shows a low or weak but definite correlation and an effect of $14.4 \%$. The results of the t-test Sig. $=0.116>$ 0.05 . tcount $=1,581<2,266$, and $\mathrm{Sig}=0.000<0.05$, and the value of tcount $=3.859>2.266$. This shows that partially the placement test has no effect while the IQ test has an effect. The results of the F test obtained the value of Sig. $=0.000<0.05$, the value of Fcount $=11.650<$ 3.062 indicates that the $\mathrm{Y}$ regression coefficient on $\mathrm{X} 1$ and $\mathrm{X} 2$ is significant or significant.

Keywords: Placement test, general intelligence (IQ), Specialization Mathematics

\section{PENDAHULUAN}

Memasuki Tahun ajaran baru 2021/2022, para orang tua dan peserta didik sudah harus mempersiapkan penerimaan siswa baru, terutama para calon peserta didik SMA, kesibukan mengurus keikutsertaan di PPDB SMA tahun pelajaran 2021/2022 dilanjutkan dengan pertimbangan memilih jurusan IPA, IPS atau Bahasa yang akan diikuti, yang cocok untuk 
dirinya, bahkan para orang tua harus saling berbagi pandangan dalam pemilihan jurusan ini, yang biasanya disetiap SMA akan dilanjutkan dengan mempertimbangkan pendapat guru BK. Orang tua tidak boleh berpandangan bahwa IPA lebih baik dari IPS, IPA dan IPS itu sama sulitnya, orang tua tidak boleh subjektif akan jurusan di SMA. Dalam petunjuk penjurusan (Depdikbud, 2013 : 12) Oleh karena itu Guru BK/Konselor harus dapat membantu peserta didik untuk menemukan kekuatannya, yang berupa kemampuan dasar umum (kecerdasan), bakat, kemampuan akademik, minat, dan kecenderungan peserta didik, serta dukungan moral dari orang tua. Seperti dijelaskan oleh Winata $(2013$ : 21) dalam artikelnya bahwa pengambilan keputusan penjurusan oleh sekolah dipertimbangkan dengan melihat beberapa faktor, antara lain nilai akademis, hasil test IQ, minat siswa, saran orang tua, dan lain sebagainya.

Penjurusan diperkenalkan sebagai upaya untuk lebih mengarahkan siswa berdasarkan minat dan kemampuan akademiknya. seperti yang dikemukakan Kadafi (2018:67) penentuan penjurusan menjadi hal yang penting dikarenakan ini menjadi salah satu langkah awal penentuan jurusan kelak jika siswa melanjutkan ke perguruan tinggi. Siswa-siswa yang mempunyai kemampuan sains dan ilmu eksakta yang baik, biasanya akan memilih jurusan IPA, dan yang memiliki minat pada sosial dan ekonomi akan memilih jurusan IPS, lalu yang gemar berbahasa akan memilih Bahasa, tetapi penjurusan di tingkat SMA tidak selalu menjamin bahwa seorang siswa akan memilih bidang studi yang sama di Universitas, karena pada kenyataannya banyak siswa program IPA yang memilih jurusan Ekonomi, Politik, Hubungan Internasional, atau siswa jurusan IPS yang memilih program Bahasa.

Untuk pemilihan jurusan, di SMA biasanya diadakan psikotes yang memuat tes bakat dan minat, dan tes kecerdasan umum (IQ). sehingga bagi sekolah, orang tua, dan peserta didik memang benar-benar tahu bakat dan minat serta IQ yang dimilikinya. Psikotest adalah serangkaian tes yang dilakukan oleh Psikolog atas permintaan sekolah, tujuannya untuk mendeskripsikan secara utuh tentang aspek-aspek psikologis seorang peserta didik supaya bisa memberikan gambaran pada setiap peserta didik yang mengikuti tes tersebut sesuai dengan kebutuhan dan keperluan sekolah. Keseluruhan proses tes ini dilakukan sesuai dengan standar pelayanan kode etik psikolog. Dengan adanya tes psikologis lebih mempermudah pihak sekolah untuk mengelompokan siswa yang memiliki kecerdasan lebih tinggi akan masuk ke dalam kelas sesuai dengan potensinya pada bidang IPA yang memuat pelajaran Matematika Minat, Fisika, Kimia dan Biologi, atau bidang IPS yang memuat pelajaran Sejarah Minat, Ekonomi, Geografi dan Sosiologi atau bidang Bahasa yang memuat pelajaran sastra Indonesia atau Sastra Bahasa Asing.

Selain psikotes ada juga sekolah yang menyelenggarakan placement test untuk mengetahui prestasi akademik dari peserta didiknya. Salah satu fungsi dari tes penempatan (Placement test) adalah sebagai pertimbangan untuk menentukan kelompok belajar yang akan diikuti oleh peserta didik, Djemari $(2012$; 111) mengatakan bahwa "pelaksanaan tes penempatan biasanya dilakukan diawal pembelajaran, hal ini dilakukan untuk mengetahui tingkat kemampuan yang telah dimiliki oleh peserta didik". Tes penempatan juga bisa diberikan untuk mengetahui keadaan, kondisi, kemampuan peserta didik sebelum proses belajar dimulai, karena tes penempatan digunakan untuk penempatan pada program pendidikan atau program belajar mengajar yang tepat sesuai dengan kemampuan yang dimiliki peserta didik. Suwarto (2012 : 127) fungsi tes penempatan digunakan untuk mendukung seberapa jauh pengetahuan awal peserta didik dalam suatu bidang studi, dengan menggunakan tes penempatan dapat membantu untuk melakukan tindak lanjut terhadap kemampuan awal yang dimiliki pesera didik. Hal ini selaras dengan tujuan penjurusan seperti yang dikemukakan oleh Nugroho dan Haryati (2015) bahwa penjurusan siswa ini bertujuan untuk mengarahkan peserta didik agar fokus mengembangkan kemampuan diri dan minat yang diliki. Jurusan yang tidak tepat bisa sangat merugikan siswa dan karirnya di masa mendatang. Selain itu tujuan penjurusan di SMA termaktub juga dalam keputusan Dirjen Mandikdasmen No. 12/C/Kep/TU/2008, 12 Februari 2008 seperti yang dikutip Kustiyahningsih dan Rahmanita (2016) yaitu Penjurusan akan disesuaikan dengan minat dan kemampuan siswa, dengan tujuan agar pembelajaran siswa 
menjadi lebih terarah. Penjurusan yang tersedia di SMA meliputi Ilmu Pengetahuan Alam (IPA), Ilmu Pengetahuan Sosial (IPS) dan bahasa.

Dengan demikian sekolah yang menyelenggarakan placement test dan psikotes dalam penjurusannya diharapkan hasilnya benar-benar menunjukan potensi peserta didik baik dari minat dan bakat, kecerdasan (IQ) dan prestasi akademiknya, sehingga sekolah atau guru dapat dengat tepat melaksanakan pembelajaran dan penilaian dalam proses belajar peserta didiknya sehingga hasil belajar peserta didiknya akan sesuai dengan tujuan yang diharapkan seperti yang termaktub dalam Permendikbud No. 23.Th 2016, Pasal 4 menyatakan bahwa "Penilaian hasil belajar oleh pendidik bertujuan untuk memantau dan mengevaluasi proses, kemajuan belajar, dan perbaikan hasil belajar peserta didik secara berkesinambungan", ini menunjukan bahwa penilaian pada peserta didik dimulai saat peserta didik itu masuk sekolah, sampai dengan saat peserta didik itu selesai mengikuti pendidikan di sekolah tersebut, demikian pula di SMA Negeri 1 Tajurhalang, untuk mencapai tujuan penilaian seperti yang diamanatkan dalam Permendikbud tersebut maka sejak awal peserta didik masuk sekolah langsung diadakan placement test dan psikotest, serta pada prosesnya diadakan penilaian baik Penilaian Tengah Semester (PTS), Penilaian Akhir Semester (PAS) dan Penilaian Akhir Tahun (PAT) serta Ujian Akhir Sekolah (UAS) seperti yang tertuang dalam Kalender akademik SMA Negeri 1 Tajurhalang Kabupaten Bogor sebagai berikut:

\begin{tabular}{|c|c|c|}
\hline & TANGGAL & KEGIATAN \\
\hline & $\begin{array}{l}4-8 \text { Oktober } \\
2021\end{array}$ & $\begin{array}{l}\text { Perkiraan Penilaian Tengah } \\
\text { semester I }\end{array}$ \\
\hline & $\begin{array}{l}27 \text { Sept - } 2 \text { Okt } \\
2021\end{array}$ & $\begin{array}{l}\text { Perkiraan Jeda Tengah Semester } \\
\text { I }\end{array}$ \\
\hline & $\begin{array}{l}6-18 \text { Desember } \\
2021\end{array}$ & $\begin{array}{l}\text { Perkiraan Penilaian Akhir } \\
\text { Semester I }\end{array}$ \\
\hline & 7 - 12 Maret 2022 & $\begin{array}{l}\text { Prakiraan Penilaian Tengah } \\
\text { Semester } 2\end{array}$ \\
\hline & Maret 2022 & $\begin{array}{l}\text { Prakiraan Ujian Akhir Sekolah } \\
\text { (UAS) }\end{array}$ \\
\hline & $\begin{array}{l}14-19 \text { Maret } \\
2022\end{array}$ & $\begin{array}{l}\text { Prakiraan Jeda Tengah Semester } \\
2\end{array}$ \\
\hline & 6 - 18 Juni 2022 & Prakiraan Penilaian Akhir Tahun \\
\hline
\end{tabular}

Berdasarkan uraian di atas maka penulis sebagai guru matematika peminatan ingin mengetahui sejauh mana pengaruh Placement test dan Kecerdasan Umum (IQ) Terhadap Hasil Belajar Matematika Peminatan Siswa Kelas X SMA Negeri 1 Tajurhalang Kabupaten Bogor.

\section{METODE PENELITIAN}

Penelitian ini bertujuan untuk mengetahui pengaruh hasil Placement Test dan test IQ terhadap hasil belajar matematika peminatan kelas X IPA di SMA Negeri 1 Tajurhalang. Metode yang digunakan penulis dalam penelitian ini adalah metode kuantitatif atau penelitian kuantitatif dengan pendekatan studi korelasional dan metode deskriptif berdasarkan hasil analisis dokumentasi. Yaitu, suatu prosedur pemecahan masalah yang diselidiki dengan menggambarkan atau melukiskan keadaan objek penelitian pada saat sekarang berdasarkan fakta-fakta yang ada sesuai dokumentasi yang dimiliki sebagaimana adanya. Populasi dalam penelitian ini adalah seluruh siswa kelas X program IPA di SMA Negeri 1 Tajurhalang yang terdiri dari 6 kelas berjumlah 218 siswa. Dengan ketentuan bahwa siswa tersebut telah mengikuti Placement Test dan test IQ serta mengikuti Tes Hasil belajar yaitu Penilaian Tengah 
Semester. Penentuan sampel dalam penelitian ini menggunakan rumus: $\mathrm{n}=\frac{N}{N(d)^{2}+1}$ dengan $\alpha=5 \%$, didapat sampel sebanyak 141 siswa.

Teknik yang digunakan dalam penentuan sampel penelitian ini adalah random sampling dengan langkah pemberian nomor urut kepada semua calon responden kemudian dengan melihat tabel bilangan acak calon responden mendapat nomor sampel. Pengambilan sampel dengan menggunakan tabel random dengan angka terkecil 1 dan angka terbesar 1000. Variabel dalam penelitian ini terdiri dari dua variabel bebas yaitu X1: Hasil Placement Test siswa kelas X IPA SMA Negeri 1 Tajurhalang Kabupaten Bogor, dan X2 : Hasil test IQ siswa Kelas X IPA SMA Negeri 1 Tajurhalang Kabupaten Bogor serta satu variabel terikat Y : Hasil belajar matematika peminatan siswa kelas X IPA SMA Negeri 1 Tajurhalang Kabupaten Bogor. Data hasil Placement Test dan hasil test IQ bersumber dari hasil Placement Test dan hasil psikotes yang diselenggarakan di SMA Negeri 1 Tajurhalang, sedangkan data Hasil belajar matematika peminatan bersumber dari hasil Penilaian Tengah Semester I atau Pekan Ulangan Semester I siswa kelas X IPA SMA Negeri 1 Tajurhalang Kabupaten Bogor. Untuk mendapatkan data yang dibutuhkan dalam penelitian ini penulis menggunakan teknik dokumentasi. data hasil Placement Test dan hasil test IQ penulis dapatkan dari guru BK serta data hasil belajar matematika minat penulis dapatkan dari guru matematika minat kelas X IPA. SMA Negeri 1 Tajurhalang untuk pelaksanaan Placement Test bekerja sama dengan Psychological Service Departement Jakarta Selatan dan psikotes bekerja sama dengan Ganesha Dwija Pertiwi Bandung, yang diselenggarakan pada tanggal 24 Juli 2021 sedangkan data hasil belajar matematika peminatan bersumber dari hasil Penilaian Tengah Semester I atau Pekan Ulangan Semester I yang dilaksanakan pada tanggal 7 Oktober 2021.

\section{HASIL DAN PEMBAHASAN}

\section{Hasil Penelitian}

\section{Analisis Deskriptif Data Hasil Penelitian}

\section{1) Analisis Deskriptif Data Hasil Belajar matematika Peminatan}

Untuk mendapatkan data hasil belajar matematika peminatan penulis bekerjasama dengan guru matematika peminatan kelas X IPA SMAN 1 Tajurhalang yang sudah melaksanakan Penilaian Tengah Semester pada tanggal 7 Oktober 2021. Berikut Penulis sajikan data hasil belajar matematika peminatan dari sampel dalam penelitian ini.

\section{Tabel 2. Data Hasil Belajar Matematika Peminatan (Y)}

\begin{tabular}{|l|l|r|}
\hline \multicolumn{2}{|c|}{ Statistics } \\
\hline $\mathrm{Y}$ & Valid & 141 \\
\cline { 2 - 3 } & Missing & 0 \\
\hline Mean & 63.37 \\
\hline Median & 70.00 \\
\hline Mode & 85 \\
\hline Std. Deviation & 24.622 \\
\hline Minimum & 5 \\
\hline Maximum & 100 \\
\hline
\end{tabular}

\section{Deskripsi}

Dari table di atas dapat penulis jelaskan bahwa hasil belajar matemtika peminatan di dapat data sebagaiberikut:

Jumlah Data

Skore Minimum $\quad: 5$

Skore Maksimum : : 100 


$\begin{array}{ll}\text { Rata-rata } & : 63,37 \\ \text { Median } & : 70,00 \\ \text { Modus } & : 85 \\ \text { Simpangan Baku } & : 24,622\end{array}$

Data hasil belajar matemtika peminatan dapat penulis sajikan dalam Histogram berikut:

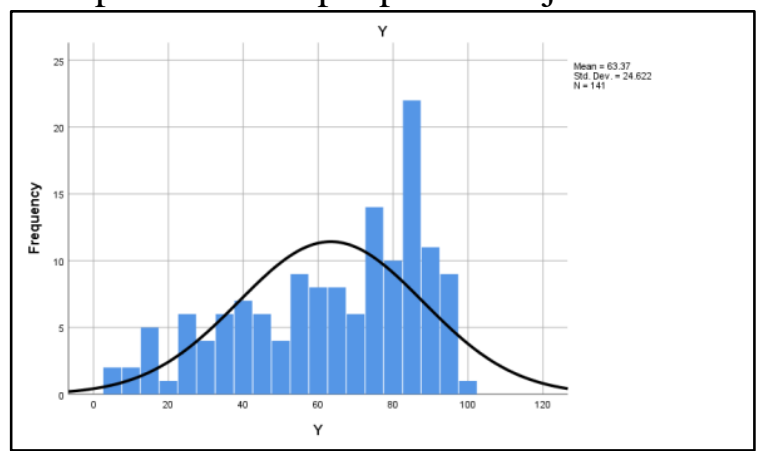

\section{Gambar 1: Histogram Data Hasil Belajar Matematika Peminatan (Y)}

\section{2) Analisis Deskriptif Data Hasil Placement Test (X1)}

Untuk mendapatkan data hasil Placement Test penulis bekerjasama dengan guru BK SMAN 1 Tajurhalang yang sudah melaksanakan Placement Test bekerjasama dengan Psychological Service Departement Jakarta Selatan pada tanggal 24 Juli 2021. Berikut Penulis sajikan data hasil Placement Test dari sampel dalam penelitian ini.

Tabel 3

Data Hasil Placement Test

\begin{tabular}{|l|l|r|}
\hline \multicolumn{2}{|c|}{ Statistics } \\
\hline $\mathrm{X} 1$ & Valid & 141 \\
\cline { 2 - 3 } & Missing & 0 \\
\hline Mean & 100.66 \\
\hline Median & 100.00 \\
\hline Mode & 110 \\
\hline Std. Deviation & 27.758 \\
\hline Minimum & 33 \\
\hline Maximum & 179 \\
\hline
\end{tabular}

Deskripsi

Dari table di atas dapat penulis jelaskan bahwa dari hasil Placement Test di dapat data sebagaiberikut:

Jumlah Data $\quad: 144$

Skore Minimum : $: 33$

Skore Maksimum : : 179

Rata-rata $\quad: 100,66$

Median $\quad: 100,00$

Modus $\quad: 110$

Simpangan Baku $\quad: 27,758$ 
Data hasil Placement Test dapat penulis sajikan dalam Histogram berikut:

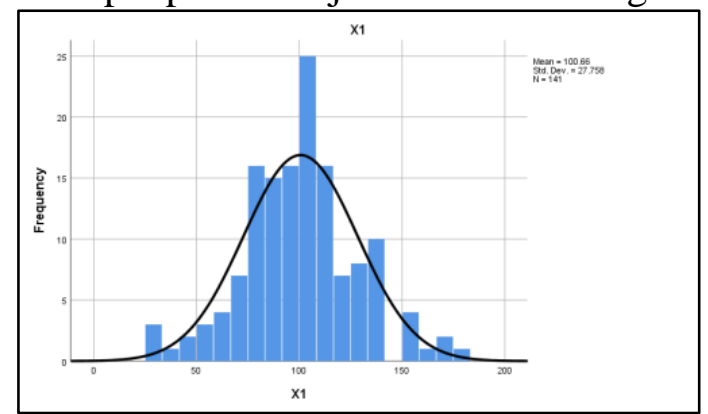

\section{Gambar 2: Histogram Data Hasil Placement Test (X1)}

\section{3) Analisis Deskriptif Data Hasil Test IQ (X2)}

Untuk mendapatkan data hasil test IQ penulis bekerjasama dengan guru BK SMAN 1 Tajurhalang yang sudah melaksanakan psikotes yang bekerjasama dengan Ganesha Dwija Pertiwi Bandung pada tanggal 24 Juli 2021. Berikut Penulis sajikan data hasil test IQ dari sampel dalam penelitian ini.

Tabel 4. Data Hasil Test IQ (X2)
\begin{tabular}{|l|r|r|}
\hline \multicolumn{2}{|c|}{ Statistics } \\
\hline $\mathrm{X} 2$ & \\
\hline $\mathrm{N}$ & Valid & 141 \\
\cline { 2 - 3 } & Missing & 0 \\
\hline Mean & 109.09 \\
\hline Median & 109.00 \\
\hline Mode & 109 \\
\hline Std. Deviation & 1.991 \\
\hline Minimum & 103 \\
\hline Maximum & 114 \\
\hline
\end{tabular}

Deskripsi

Dari table di atas dapat penulis jelaskan bahwa dari hasil test IQ di dapat data sebagaiberikut:

Jumlah Data $\quad: 114$

Skore Minimum : :103

Skore Maksimum $\quad: 114$

Rata-rata $\quad: 109,09$

Median $\quad: 109,00$

Modus : : 109

Simpangan Baku $\quad: 1,991$

Data hasil Test IQ dapat penulis sajikan dalam Histogram berikut:

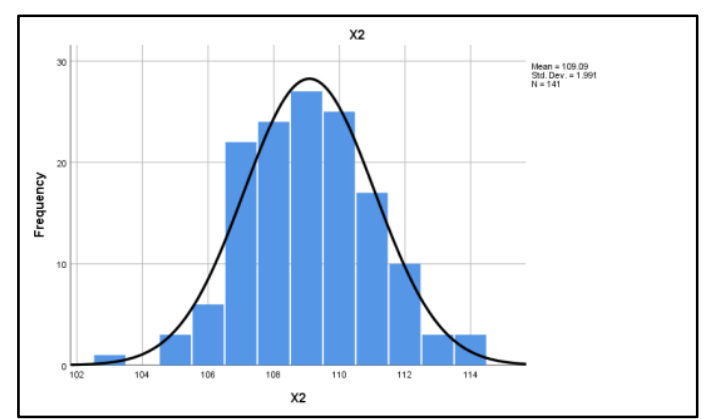

Gambar 3: Histogram Data Hasil Test IQ (X2) 


\section{Uji Regresi Linier Berganda}

1) Uji Asumsi Klasik Normalitas Data hasil penelitian

Untuk mengetahui bahwa data hasil penelitian berasal dari data yang distribusi normal penulis menguji data hasil penelitian dengan uji normalitas $\boldsymbol{P}-\boldsymbol{P}$ plot of Regresion Standardized Residual dengan asumsi bahwa jika titik berada pada sekitar garis diagonal maka dikatanan bahwa data berasal dari distribusi normal, berikut penulis sajikan hasil uji normalitas data hasil penelitian sebagai berikut:

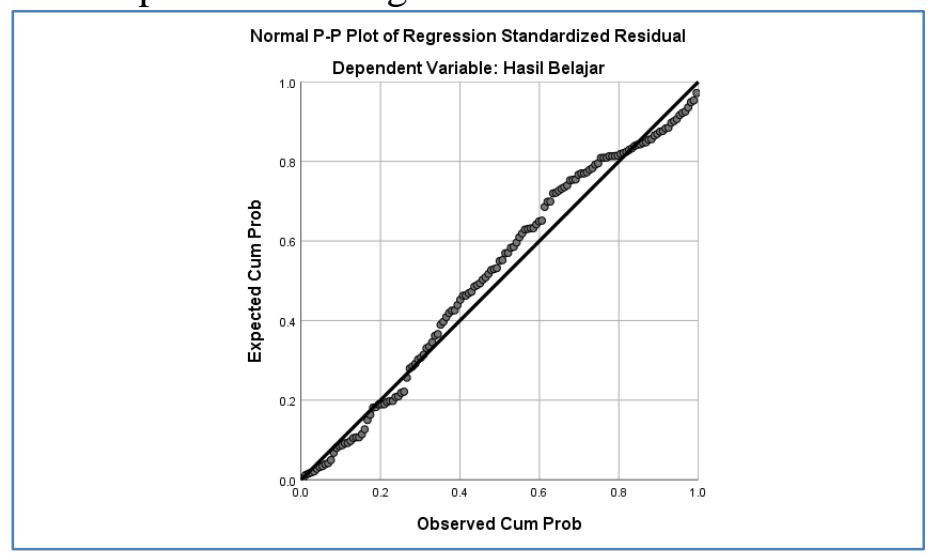

Gambar 4: Uji Normalitas Data Hasil penelitian

Dari gambar 4: diatas Nampak bahwa titik-titik berada pada sekitar garis diagonal, hal ini menunjukan bahwa data hasil penelitian berasal dari data yang berdistribusi normal.

\section{2) Uji Multikolinearitas}

pada pengujian multikolinearitas bertujuan untuk mengetahui apakah model regresi ditemukan adanya korelasi antar variabel independent atau variable bebas. Untuk menemukan terdapat atau tidaknya multikolinearitas pada model regresi dapat diketahui dari nilai toleransi dan nilai variance inflation factor (VIF). Dengan asumsi jika nilai tolerance $>0,1$ dan nilai VIF $<10$ maka dikatakan bahwa pada variabel bebas tidak terjadi multikolonearitas. Berikut penulis sajikan hasil uji multikolinearitas data hasil penelitian seperti pada tabel 5 .

Tabel 5. Hasil Uji Multikolinieritas

\begin{tabular}{|c|c|c|c|c|c|c|c|c|}
\hline \multicolumn{9}{|c|}{ Coefficients $^{\mathrm{a}}$} \\
\hline \multirow{2}{*}{\multicolumn{2}{|c|}{ Model }} & \multicolumn{2}{|c|}{$\begin{array}{l}\text { Unstandardized } \\
\text { Coefficients }\end{array}$} & \multirow{2}{*}{$\begin{array}{c}\begin{array}{c}\text { Standardize } \\
\text { d } \\
\text { Coefficient } \\
\text { s }\end{array} \\
\text { Beta } \\
\end{array}$} & \multirow[b]{2}{*}{$\mathrm{t}$} & \multirow[b]{2}{*}{ Sig. } & \multicolumn{2}{|c|}{$\begin{array}{l}\text { Collinearity } \\
\text { Statistics }\end{array}$} \\
\hline & & $\mathrm{B}$ & $\begin{array}{l}\text { Std. } \\
\text { Error }\end{array}$ & & & & $\begin{array}{c}\text { Toleranc } \\
\mathrm{e}\end{array}$ & VIF \\
\hline 1 & $\begin{array}{l}\text { (Consta } \\
\text { nt) }\end{array}$ & $\begin{array}{r}- \\
378.81 \\
3\end{array}$ & 109.543 & & 3.458 & .001 & & \\
\hline & $\begin{array}{l}\text { Placeme } \\
\text { nt Test }\end{array}$ & .116 & .073 & .131 & 1.581 & .116 & .907 & 1.103 \\
\hline & Test IQ & 3.947 & 1.023 & .319 & 3.859 & .000 & .907 & 1.103 \\
\hline
\end{tabular}

Tampak bahwa nilai tolerance untuk placement test dan test IQ sebesar 0,907 hal ini lebih besar dari 0,1 dan nilai VIF sebesar 1.103 hal ini lebih kecil dari 10. Sehingga dapat disimpulkan bahwa variabel independen pada data hasil penelitian tidak terjadi multikolinearitas. 


\section{3) Uji Heteroskedastisitas dan Linieritas Regresi Y atas X1 dan X2}

Uji ini bertujuan untuk melakukan uji apakah pada sebuah model regresi terjadi ketidaknyamanan varian dari residual dalam satu pengamatan ke pengamatan lainnya. Apabila varian berbeda, disebut heteroskedastisitas. Salah satu cara untuk mengetahui ada tidaknya heteroskedastisitas pada suatu model regresi linier berganda, yaitu dengan melihat grafik scatterplot atau dari nilai prediksi variabel terikat yaitu SRESID dengan residual error yaitu ZPRED. Apabila tidak terdapat pola tertentu dan tidak menyebar diatas maupun dibawah angka nol pada sumbu y, maka dapat disimpulkan tidak terjadi heteroskedastisitas. Berikut penulis sajikan hasil uji heteroskedastisitas data hasil penelitian seperti pada gambar 5 .

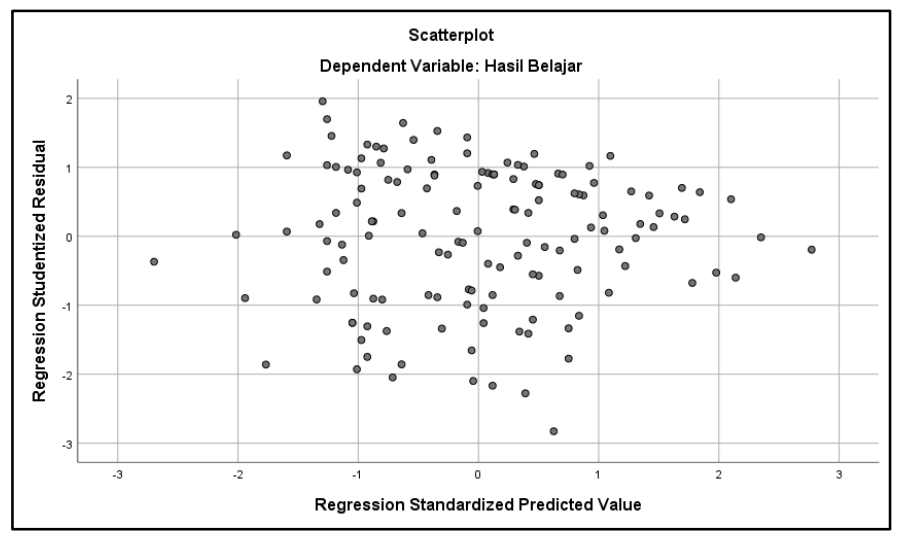

Gambar 5: Uji Heteroskedastisitas

Pada gambar 5; Tampak bahwa tidak terdapat pola tertentu dan tidak menyebar diatas maupun dibawah angka nol pada sumbu y, hal ini menunjukan bahwa pada data hasil penelitian tidak terjadi Heteroskedastisitas. Berdasarkan plot residual dengan fitted value tersebut, terlihat bahwa tebaran nilai-nilai pada plot membentuk suatu pola acak, sehingga asumsi linieritas terpenuhi.

\section{Pengujian Hipotesis Penelitian (Analisis Inferensial)}

1) Uji Koefesien Korelasi Antara $X 1$ dan $X 2$ dengan $Y$

Hasil uji koefesien korelasi antara hasil Placement Test dan test IQ dengan hasil belajar matematika peminatan penulis sajikan dalam table berikut ini:

Tabel 6. Uji Koefesien Korelasi antara Hasil Placement Test dan Hasil Test IQ dengan Hasil Belajar

\begin{tabular}{|c|c|c|c|c|c|}
\hline \multicolumn{6}{|c|}{ Model Summary } \\
\hline $\begin{array}{l}\text { Mod } \\
\text { el }\end{array}$ & $\mathrm{R}$ & $\begin{array}{c}\mathrm{R} \\
\text { Square }\end{array}$ & $\begin{array}{c}\text { Adjusted R } \\
\text { Square }\end{array}$ & $\begin{array}{l}\text { Std. Error of } \\
\text { the Estimate }\end{array}$ & $\begin{array}{c}\text { Durbi } \\
n- \\
\text { Watso } \\
n\end{array}$ \\
\hline 1 & $\begin{array}{r}.380 \\
\mathrm{a}\end{array}$ & .144 & .132 & 22.939 & 1.823 \\
\hline
\end{tabular}

Tampak pada tabel 6. di atas bahwa nilai $\mathrm{R}=0,380$, hal ini menunjukan korelasi antara hasil Placement Test dan hasil test IQ dengan Hasil belajar matematika peminatan memiliki korelasi yang rendah atau lemah tapi pasti. Nilai $\mathrm{R}$ Square $=0,144$, ini menunjukan bahwa pengaruh hasil Placement Test dan hasil test IQ terhadap hasil belajar matematika peminatan kelas X IPA SMAN 1 Tajurhalang sebesar 14,4\% yang merupakan pengaruh yang kecil. 


\section{2) Uji Parsial Koefesien Regresi Y atas X1 dan X2}

a. Persamaan Regresi Berganda $Y$ atas X1 dan X2.

Untuk mengetahui persamaan regresi berganda $\mathrm{Y}$ atas $\mathrm{X} 1$ dan $\mathrm{X} 2$ penulis menguji koefesien regresi parsial $\mathrm{Y}$ atas $\mathrm{X} 1$ dan $\mathrm{X} 2$ dengan uji t seperti pada tabel berikut ini.

Tabel 7. Uji Koefesien Regresi Y atas X1 dan X2

\begin{tabular}{|c|c|c|c|c|c|c|c|c|}
\hline \multicolumn{9}{|c|}{ Coefficients $^{\mathrm{a}}$} \\
\hline \multirow{2}{*}{\multicolumn{2}{|c|}{ Model }} & \multicolumn{2}{|c|}{$\begin{array}{l}\text { Unstandardized } \\
\text { Coefficients }\end{array}$} & \multirow{2}{*}{$\begin{array}{c}\text { Standardize } \\
\mathrm{d} \\
\text { Coefficient } \\
\mathrm{s}\end{array}$} & \multirow[b]{2}{*}{$\mathrm{t}$} & \multirow[b]{2}{*}{ Sig. } & \multicolumn{2}{|c|}{$\begin{array}{l}\text { Collinearity } \\
\text { Statistics }\end{array}$} \\
\hline & & $\mathrm{B}$ & $\begin{array}{l}\text { Std. } \\
\text { Error }\end{array}$ & & & & $\begin{array}{c}\text { Toleranc } \\
\mathrm{e}\end{array}$ & VIF \\
\hline & $\begin{array}{l}\text { (Consta } \\
\text { nt) }\end{array}$ & $\begin{array}{r}- \\
378.81 \\
3\end{array}$ & 109.543 & & 3.458 & .001 & & \\
\hline & $\begin{array}{l}\text { Placeme } \\
\text { nt Test }\end{array}$ & .116 & .073 & .131 & 1.581 & .116 & .907 & 1.103 \\
\hline & Test IQ & 3.947 & 1.023 & .319 & 3.859 & .000 & .907 & 1.103 \\
\hline
\end{tabular}

a. Dependent Variable: Hasil Belajar

Dari tabel 7. Di atas tampak bahwa konstanta regresi $\mathrm{Y}$ atas X1 dan X2 adalah 378.813 dan koefesien regresi hasil Placement Test 0,116 serta koefesien regresi hasil test IQ adalah 3,947, hai ini menunjukan bahwa persamaan regresi $\mathrm{Y}$ atas X1 dan X2 adalah $\mathrm{Y}=-378,813+0,116 \mathrm{X} 1+3,947 \mathrm{X} 2$. Dengan nilai koefesien regresi yang positif ini menunjukan bahwa setiap kenaikan nilai hasil placement test akan menaikan hasil belajar sebesar 0,116 nya ditambah kenaikan hasil test IQ sebesar 3,947 nya.

\section{b. Uji Signifikansi koefesien regresi Parsial Y atas X1 dan X2}

Pada tabel 7: tampak bahwa pada uji t nilai signifikan untuk placement test sebesar 0,116 yang lebih besar dari 0,05 . Nilai t table untuk $\alpha=0,05, \mathrm{dk}=(\mathrm{n}-\mathrm{k}-1)$ yaitu $\mathrm{t}(0,025 ; 138)=2,266$. untuk placement test nilai $t_{\text {hitung }}=1,581<2,266$, hal ini menunjukan bahwa placement test secara parsial tidak berpengaruh terhadap hasil belajar matematika peminatan, sedangkan nilai signifikan untuk test IQ sebesar 0,000 yang lebih kecil dari 0,05 , dan nilai $t_{\text {hitung }}=3,859>2,266$. hal ini menunjukan bahwa test IQ secara parsial berpengaruh terhadap hasil belajar matematika peminatan.

\section{3) Uji Signifikansi Koefesien Regresi Berganda Y atas X1 dan X2}

Hasil Uji Sinifikan koefesien regresi Hasil Belajar (Y) atas hasil Placement Test (X1) dan test IQ (X2) penulis sajikan dalam tabel berikut:

Tabel 8. Uji Signifikan Koefesien Regresi Y atas X1 dan X2

\begin{tabular}{|c|c|c|c|c|c|c|}
\hline \multicolumn{7}{|c|}{ ANOVA $^{a}$} \\
\hline \multicolumn{2}{|c|}{ Model } & $\begin{array}{l}\text { Sum of } \\
\text { Squares }\end{array}$ & df & $\begin{array}{c}\text { Mean } \\
\text { Square }\end{array}$ & $\mathrm{F}$ & Sig. \\
\hline 1 & $\begin{array}{l}\text { Regressio } \\
\mathrm{n}\end{array}$ & $\begin{array}{r}12260.6 \\
39 \\
\end{array}$ & 2 & $\begin{array}{r}6130.32 \\
0\end{array}$ & $\begin{array}{r}11.65 \\
0 \\
\end{array}$ & $.000^{\mathrm{b}}$ \\
\hline & Residual & $\begin{array}{r}72614.1 \\
83\end{array}$ & 138 & 526.190 & & \\
\hline & Total & $\begin{array}{r}84874.8 \\
23\end{array}$ & 140 & & & \\
\hline
\end{tabular}


b. Predictors: (Constant), Test IQ, Placement Test

Nilai Signifikan dari hasil placement test dan hasil test IQ adalah 0,000 hal ini lebih kecil dari 0,05 , nilai $\mathrm{F}$ table untuk $\alpha=0,05 \mathrm{dk} 1=\mathrm{k}$ dan $\mathrm{dk} 2=(\mathrm{N}-\mathrm{k}-1)=\mathrm{F}(0,05 ; 2,138)=3,062$ sedangkan $F_{\text {hitung }}=11,650$ lebih besar dari 3,062 yang menunjukan bahwa koefesien regresi $\mathrm{Y}$ atas $\mathrm{X} 1$ dan $\mathrm{X} 2$ signifikan atau berarti. Dengan demikian dapat disimpulkan bahwa pengujian Hipotesis terdapat pengaruh hasil placement test dan test IQ terhadap hasil belajar matematika peminatan di kelas XI IPA SMAN 1 Tajurhalang Kabupaten Bogor terbukti.

\section{Pembahasan}

\section{Analisis Deskriptif Hasil Penelitian}

Dari analisis deskriptif data hasil penelitian untuk hasil belajar matematika peminatan (Y) didapat nilai minimum 5, nilai maksimum 100, rata-rata 63,37, median 70,00, modus 85 dan simpangan baku 24,622, untuk placement test didapat nilai minimum 33, nilai maksimum 179 , rata-rata 100,66, median 100, modus 110 dan simpangan baku 27,758, untuk test IQ didapat nilai minimum 103, skor maksimum 114, rata-rata 109,09, median 109,00, modus 109 dan simpangan baku 1,991.

\section{Uji Asumsi Klasik}

Hasil uji normalitas data didapat bahwa titik-titik berada dekat dengan garis diagonal yang menunjukan bahwa semua data hasil penelitian merupakan data yang berasal dari data yang berdistribusi normal, dan hasil uji multikolinieritas didapat nilai tolerance 0,907 >0,100 dan nilai VIF sebeasr1,103 < 10 hal ini menunjukan bahwa pada data hasil penelitian tidak terjadi multikolinieritas, hasil uji heteroskediritas bahwa titik titik menyebar dan tidak membentuk pola hal ini menunjukan bahwa pada data hasil penelitian tidak terjadi heteroskedisitas, berdasarkan plot residual dengan fitted value terlihat bahwa sebaran nilai-nilai pada plot membentuk suatu pola acak, sehingga asumsi linieritas terpenuhi.

\section{Uji Koefesien Korelasi Antara X1 dan X2 dengan Y}

Hasil uji koefesien korelasi antara $\mathrm{X} 1$ dan $\mathrm{X} 2$ dengan $\mathrm{Y}$ didapat nilai $\mathrm{R}=0,380$, hal ini menunjukan korelasi antara hasil placement test dan hasil test IQ dengan hasil belajar matematika peminatan memiliki korelasi yang rendah atau lemah tapi pasti. Nilai R Square $=0,144$, ini menunjukan bahwa pengaruh hasil placement test dan hasil test IQ terhadap hasil belajar matematika peminatan kelas X IPA SMAN 1 Tajurhalang sebesar 14,4\% yang merupakan pengaruh yang kecil.

\section{Uji Regresi Parsial Y atas X1 dan X2}

persamaan regresi $\mathrm{Y}$ atas $\mathrm{X} 1$ dan $\mathrm{X} 2$ adalah $\mathrm{Y}=-378,813+0,116 \mathrm{X} 1+3,947 \mathrm{X} 2$. Dengan nilai koefesien regresi yang positif ini menunjukan bahwa setiap kenaikan nilai hasil placement test akan menaikan hasil belajar matematika peminatan sebesar 0,116 nya ditambah kenaikan hasil test IQ sebesar 3,947 nya.

Hasil uji t nilai signifikan untuk placement test sebesar 0,116 yang lebih besar dari 0,05. $t_{\text {hitung }}=1,581<2,266$, hal ini menunjukan bahwa placement test secara parsial tidak berpengaruh terhadap hasil belajar matematika peminatan, sedangkan nilai signifikan untuk test IQ sebesar 0,000 yang lebih kecil dari 0,05, dan nilai $t_{\text {hitung }}=3,859>2,266$. hal ini menunjukan bahwa test IQ secara parsial berpengaruh terhadap hasil belajar matematika peminatan.

\section{Uji Signifikansi Koefesien Regresi Berganda $Y$ atas $X 1$ dan $X 2$}

Hasil Uji Sinifikan koefesien regresi Hasil Belajar (Y) atas hasil Placement Test (X1) dan test IQ (X2) didapat nilai Signifikan dari hasil placement test dan hasil test IQ adalah 0,000 hal ini lebih kecil dari 0,05, nilai $F_{\text {hitung }}=11,650$ lebih besar dari $\mathrm{F}$ table $=3,062$ yang 
menunjukan bahwa koefesien regresi $\mathrm{Y}$ atas $\mathrm{X} 1$ dan $\mathrm{X} 2$ signifikan atau berarti. Dengan demikian dapat disimpulkan bahwa pengujian Hipotesis terdapat pengaruh hasil placement test dan test IQ terhadap hasil belajar matematika peminatan di kelas XI IPA SMAN 1 Tajurhalang Kabupaten Bogor terbukti.

Hal ini sesuai dengan beberapa penelitian yang telah dilakukan sebelumnya seperti Purnamaningsih (2013) proses penentuan penjurusan siswa SMA dengan teknik clustering menggunakan metode K-Means clustering, yang menjadikan nilai IQ dan minat siswa sebagai dasar dalam penentuan penjurusan siswa SMA selain nilai akademik. Irawan AS (2014) menjadikan nilai raport atau nilai akademik dan nilai psikotes, nilai IQ dan minat siswa sebagai dasar dalam penelitiannya tentang Sistem Pendukung Keputusan penjurusan berdasarkan perhitungan Analytical hierarchy Process (AHP). Winata (2013) Implementasi Metode Bayesian Dalam Penjurusan Di SMA Bruderan Purworejo juga menggunakan nilai akademis, hasil test IQ, minat siswa, saran orang tua dan lain sebagainya dalam penentuan penjurusan di SMA Brunderan Purworejo.

\section{KESIMPULAN}

Berdasarkan hassil analisis data didapat kesimpulan sebagai berikut:

\section{Uji Koefesien Korelasi Antara X1 dan X2 dengan Y}

Hasil uji koefesien korelasi antara Hasil Placement Tes (X1) dan tst IQ (X2) dengan Hasil Belajar Matematika Peminatan (Y) didapat nilai $\mathrm{R}=0,380$, hal ini menunjukan korelasi antara hasil placement test (X1) dan hasil test IQ (X2) dengan hasil belajar matematika peminatan (Y) memiliki korelasi yang rendah atau lemah tapi pasti. Nilai R Square $=0,144$, ini menunjukan bahwa pengaruh hasil placement test dan hasil test IQ terhadap hasil belajar matematika peminatan kelas X IPA SMAN 1 Tajurhalang sebesar 14,4\% dan sebesar 85,6\% dari faktor lainya, Hal ini dimungkinkan karena kurang siapnya siswa dalam mengikuti placement test dan test IQ atau karena pelaksanaan test nya dalam satu hari yang sama sehingga kondisi siswa untuk mengikuti test sudah berkurang. Selain itu pelaksanaan placement test, test IQ dan Penilaian Tengah Semester dilaksanakan pada masa pandemik Covid'19 sehingga menggunakan cara daring atau Online. Sehingga sangat mempengaruhi hasil test tersebut.

\section{Uji Regresi Parsial Y atas X1 dan X2}

Persamaan regresi $\mathrm{Y}$ atas $\mathrm{X} 1$ dan $\mathrm{X} 2$ adalah $\mathrm{Y}=-378,813+0,116 \mathrm{X} 1+3,947 \mathrm{X} 2$. Dengan nilai koefesien regresi yang positif ini menunjukan bahwa setiap kenaikan nilai hasil placement test akan menaikan hasil belajar matematika peminatan sebesar 0,116 nya ditambah kenaikan hasil test IQ sebesar 3,947 nya. Hasil uji t nilai signifikan untuk placement test sebesar 0,116 yang lebih besar dari 0,05 . $_{\text {hitung }}=1,581<2,266$, hal ini menunjukan bahwa placement test secara parsial tidak berpengaruh terhadap hasil belajar matematika peminatan, sedangkan nilai signifikan untuk test IQ sebesar 0,000 yang lebih kecil dari 0,05 , dan nilai $t_{\text {hitung }}=3,859>2,266$. hal ini menunjukan bahwa test IQ secara parsial berpengaruh terhadap hasil belajar matematika peminatan. Dengan demikian diharapkan pelaksanaan placement test dimasa yang akan datang perlu lebih disipkan dan di tingkatkan kualitasnya agar dapat berpengaruh langsung terhadap hasil belajar matematika minat.

\section{Uji Signifikansi Koefesien Regresi Berganda Y atas X1 dan X2}

Hasil Uji Sinifikan koefesien regresi Hasil Belajar Matematika Peminatan (Y) atas hasil Placement Test (X1) dan test IQ (X2) didapat nilai Signifikan dari hasil placement test dan hasil test IQ adalah 0,000 hal ini lebih kecil dari 0,05, dan nilai $F_{\text {hitung }}=11,650$ lebih besar dari $\mathrm{F}$ table $=3,062$ yang menunjukan bahwa koefesien regresi $\mathrm{Y}$ atas $\mathrm{X} 1$ dan $\mathrm{X} 2$ signifikan atau berarti. Dengan demikian dapat disimpulkan bahwa pengujian Hipotesis terdapat 
pengaruh hasil placement test dan test IQ terhadap hasil belajar matematika peminatan di kelas XI IPA SMAN 1 Tajurhalang Kabupaten Bogor terbukti.

\section{DAFTAR PUSTAKA}

Badan Pengembangan Sumber Daya Manusia Pendidikan dan Kebudayaan dan Penjaminan Mutu Pendidikan Kementerian Pendidikan dan Kebudayaan Pedoman Peminatan Peserta Didik, Tahun 2013

D Mardapi. (2012). Pengukuran penilaian dan evaluasi pendidikan. Yogyakarta: Nuha Medika 45

Hasan Iqbal. (2006). Analisis Data Penelitian dengan Statistik. Jakarta: Bumi Aksara

Imam Ghozali 2011. Aplikasi Analisis Multivariat dengan Program IBM SPSS 19. Semarang. Badan Penerbit Undip.

Irawan AS. (2014). Sistem Pendukung Keputusan Pemilihan Jurusan Di SMA Islam Sudirman Ambarawa Menggunakan Metode Analytical Hierarchy Process (AHP) : Jurnal Mahasiswa Stekom Semarang. Academi.edu

Kustiyahningsih Yeni dan Rahmanita Eza. (2016). Aplikasi Sistem Pendukung Keputusan Menggunakan Algoritma C4.5. Untuk Penjurusan SMA. Jurnal Simante C. Vol. 5, No. 2.

Permendikbud No.23 Tahun 2016 Tentang Standar Penilaian Pendidikan

Purnamaningsih C. (2013). Pemanfaatan Metode K-Means Clustering Dalam Penentuan Penjurusan Sisa SMA. digilig.UNS.ac.id

Rahman, Abdul Kadafi. (2018). Perbadingan Algoritma Klasifikasi Untuk Penjurusan Siswa SMA. Eltikom : Jurnal Teknik Elektro, Teknologi, dan Komputer, Vol. 2, No. 2

Suwarto. (2012). Pengembangan Tes Diagnostik dalam Pembelajaran. Jogjakarta: Graha Ilmu V. Wiratna Sujarweni. (2014). SPSS untuk penelitian. Yogyakarta. Pustaka baru Press

Winata Sendy. (213). Implementasi Metode Bayesian dalam Penjurusan di SMA Bruderan Purwokwrto. Jurnal EKSIS, Vol 06 No 02

Yusuf S, Nugroho dan Syarifah N, Haryati. (2015). Klasifikasi dan Klastering Penjurusan Siswa SMA Negeri 3 Boyolali. Khazanah Informatika : Jurnal Ilmu Komputer dan Informatika, Vol. 1 No. 1. 